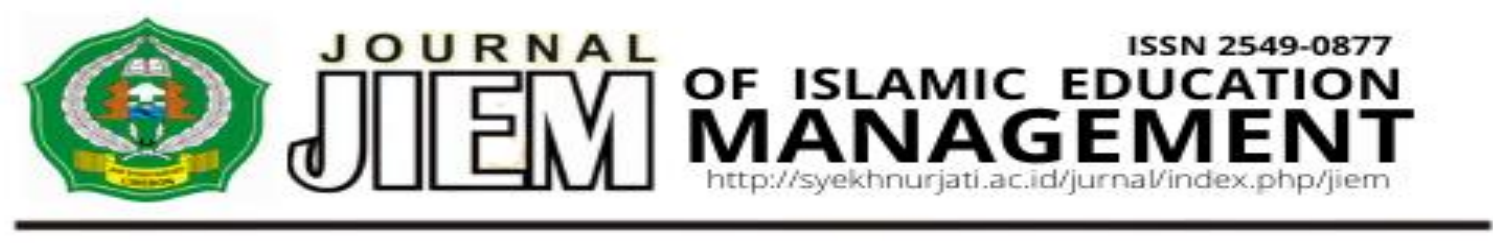

\title{
SUPERVISI KELAS OLEH KEPALA SEKOLAH CLASSROOM SUPERVISION BY THE PRINCIPAL
}

\author{
Ahmad Amin Mubarok \\ Institute Agama Islam Negeri Syekh Nurjati Cirebon \\ Email : ahmadaminmubarok@gmail.com
}

\begin{abstract}
ABSTAK
Sekolah sebagai lembaga pendidikan formal bertujuan membentuk manusia yang berkepribadian, dalam mengembangkan intelektual peserta didik dalam rangka mencerdaskan kehidupan bangsa. Kepala sekolah sebagai pemimipin pendidikan perannya sangat penting untuk membantu guru dan muridnya. Di dalam kepemimpinnya kepala harus dapat memahami, mengatasi dan memperbaiki kekurangan-kekurangan yang terjadi di lingkungan sekolah, salah satunya dengan mengoptimalkan fungsi kepala sekolah sebagai supervisor. Kepala sekolah sebagai supervisor harus mewujudkan kemampuan menyusun, dan melaksanakan program supervisi pendidikan, serta memanfaatkan hasilnya. Kemampuan menyusun program supervisi pendidikan harus diwujudkan dalam penyusunan program supervisi kelas, pengembangan program supervisi untuk kegiatan ekstra kurikuler, pengembangan program supervisi perpustakaan, laboratorium, dan ujian. Kemampuan melaksanakan program supervisi pendidikan harus diwujudkan dalam pelaksanaan program supervisi klinis, program supervisi nonklinis, dan program supervisi kegiatan ekstra kurikuler. Sedangkan kemampuan memanfaatkan hasil supervisi pendidikan harus diwujudkan dalam pemanfaatan hasil supervisi untuk meningkatkan kinerja tenaga kependidikan, dan pemanfaatan hasil supervisi untuk mengembangkan sekolah.
\end{abstract}

Kata Kunci: Kepala Sekolah, Supervisor, Supervisi Kelas, Supervisi Pendidikan.

\section{ABSTRACT}

As organization of formal education, school has the aim to form human being having good personality. To develop intellectual student in order to make our people more diligent. The Principal as educational leader has key position to help teacher and student. In his leadership, Principal must understand, solve and repaire school field deficiency, one of them is optimalizing functions of Principal as supervisor. A principal as supervisor has to actualize composing ability, apply educational supervision program, and benefit its outcome. Ability to compose educational supervision program must be actualized in composing supervision class program, development of eks-school supervision program, development of library supervision program, laboratory and examination. Ability to apply educational supervision program must be actualized in realizing clinic and non clinic supervision program and also eks-school supervision program. Whereas ability to benefit supervision yield to rise up occupation of education manpower and benefit of supervision yield for developing school.

Keyword: The Principal, Supervisor, classroom supervision, educational scientific. 


\section{A. PENDAHULUAN}

Akhir-akhir ini, pendidikan di sekolah telah mengalami suatu perubahan yang cukup signifikan, baik dari sisi sarana maupun kualitas lulusan suatu sekolah, meskipun disadari atau tidak, kualitas pendidikan kita masih jauh dari yang diharapkan oleh dunia global. Penyebabnya adalah bahwa daya saing SDM kita masih rendah, seperti yang diungkapkan Sonhaji (2006: 21) bahwa dalam menghadapi persaingan global dewasa ini, Indonesia memiliki daya saing yang rendah disebabkan rendahnya SDM, sedangkan pendidikan merupakan upaya peningkatan kualitas SDM yang efektif. Kondisi ini dapat dicapai apabila kegiatan supervisi dilaksanakan dengan benar sesuai dengan proporsinya. Sering kita melihat sekolah-sekolah dari segi infrastrukturnya memiliki bangunan yang tinggi, mewah dan bahkan berbeda dengan bangunanbangunan di sekitarnya, tidak hanya itu, fasilitas-fasilitas modern pun lengkap dan tersedia di sekolah. Kemajuan-kemajuan yang dirasa ada sekarang ini merupakan hasil kerja keras para praktisi pendidikan, stake holder, dewan guru, siswa dan masyarakat maupun peranan kepala sekolah itu sendiri.

Tidak bisa dipungkiri, bahwa adanya kepala sekolah dalam institusi sekolah sangat berperan besar dalam menentukan maju-mundurnya suatu sekolah meskipun pada tataran praktisnya para guru adalah pejuang utama dalam pencapaian kemajuan tersebut. Namun, sebagai seorang pemimpin maka kepala sekolah memiliki tugas yang sangat besar dan tanggungjawab yang besar pula untuk memberikan ciri dan warna maupun corak terhadap kualitas sekolah yang dipimpinnya, sebagaimana tertuang dalam Permendikbud no. 6 tahun 2018.

Seorang kepala sekolah akan diuji dan diketahui baik buruk peranannya diantaranya yaitu dari sisi supervisi terhadap guru. Seorang kepala sekolah bisa dikatakan sukses yaitu apabila telah melaksanakan segala prosedur supervisi secara sistematis dan akuntabel. Dikatakan sistem karena setiap unsur-unsur yang ada dalam supervisi merupakan suatu kesatuan petunjuk yang harus dilakukan secara menyeluruh dan berurutan, tidak setengahsetengah atau sebagian saja.

Beberapa prinsip-prinsip Supervisi semestinya sudah dikuasai oleh seorang kepala sekolah sehingga dalam pelaksanaan supervisi tersebut tidak jauh menyimpang dari ketentuan yang ada. Oleh karena itu, seorang kepala sekolah harus benar-benar menguasai konsep dasar supervisi, teknik-teknik supervisi sampai pada penilaian dan perbaikan bagi guru, karena hakikat supervisi adalah membantu guru untuk meningkatkan kompetensinya.

Supervisi yang dilakukan oleh kepala sekolah, merupakan supervisi secara langsung, karena kepala sekolah mempunyai peluang waktu yang sangat besar untuk bisa bertatap muka dengan dewan guru, sehingga bila peranan kepala sekolah sebagai seorang supervisor itu terlaksana dengan baik maka akan membentuk mutu sekolah yang baik pula.

$$
\text { Kepala sekolah dalam }
$$

kedudukannya sebagai supervisor berkewajiban melaksanakan pembinaan kepada para guru baik secara preventif maupun kuratif dalam rangka menciptakan atmosfir kegiatan pembelajaran yang efektif dan efisien. Efektifitas dan efisiensi Kegiatan belajar mengajar sangat bergantung pada profesionalitas guru mata pelajaran yang langsung bersentuhan dengan siswa. Supervisi yang dilakukan oleh kepala sekolah setidaknya akan bermuara pada keberhasilan proses pembelajaran.

Dari paparan di atas, kiranya bisa kita garisbawahi bahwa peranan kepala sekolah salah satunya adalah sebagai supervisor. Oleh karena Supervisi adalah salah satu kegiatan penting dalam mewujudkan sekolah yang baik dan guru yang supervisi sesuai dengan kompetensinya, maka tulisan kali ini akan 
memaparkan secara sederhana tentang peranan kepala sekolah sebagai supervisor.

\section{B. Rumusan Masalah}

Dari latar belakang masalah di atas, ada beberapa masalah yang bisa dirumuskan, yaitu:

1. Apakah tugas dan fungsi kepala sekolah sebagai supervisor pendidikan?

2. Bagaimanakah upaya kepala sekolah untuk meningkatkan kompetensi professional guru?

3. Apa sajakah teknik-teknik supervisi kepala sekolah untuk meningkatkan kompetensi professional guru?

\section{Tujuan Penulisan}

Penulisan jurnal ilmiah ini bertujuan sebagai berikut:

1. Mengetahui tugas dan fungsi kepala sekolah sebagai supervisor pendidikan.

2. Mengetahui upaya kepala sekolah untuk meningkatkan kompetensi professional guru.

3. Mengetahui teknik-teknik supervisi kepala sekolah untuk meningkatkan kompetensi professional guru.

\section{Metode Kajian}

Metode yang digunakan dalam kajian jurnal ini adalah studi pustaka (literature research). Salah satu tujuan dalam melakukan telaah kepustakaan adalah melakukan sintesa dan memperoleh perspektif baru terkait tema yang sedang diangkat.

\section{SUPERVISI KELAS OLEH KEPALA SEKOLAH}

\section{A. Pengertian Kepala Sekolah dan Supervisi}

Berbicara mengenai definisi kepala sekolah maka akan didapati dua kata, yaitu "kepala"dan "sekolah". Kepala diartikan sebagai pemimpin dalam suatu organisasi yang diangkat berdasarkan keputusan, dan sekolah berarti sebuah lembaga pendidikan dasar dan menengah yang bersifat formal. Hal tersebut berarti bahwa kepala sekolah merupakan seorang tenaga fungsional guru yang diberi tugas untuk memimpin suatu sekolah di mana diselenggarakan proses belajar mengajar, atau tempat di mana terjadi interaksi antara guru yang 15 cient pelajaran dan murid yang menerima pelajaran (Wahjosumidjo, 2010:83). Kepala sekolah juga merupakan manajer pendidikan tingkat sekolah dan ujung tombak utama dalam mengelola pendidikan di level sekolah. Kepala sekolah sebagai seorang pimpinan di sekolah bertanggung jawab terhadap seluruh kegiatan sekolah yakni; mengatur proses belajar-mengajar, mengatur hal-hal yang menyangkut kesiswaan, personalia, sarana dan prasarana yang dibutuhkan dalam pelajaran, ketatausahaan, keuangan, serta mengatur hubungan dengan masyarakat (Jamal Ma'mur Asmani, 2012:53).

Kepala sekolah memiliki kedudukan sebagai administrator dan supervisor. Dalam Peraturan Menteri Pendidikan Nasional Nomor 13 Tahun 2007 tentang Standar Kepala Sekolah/ Madrasah disebutkan bahwa kepala sekolah memiliki tugas dan peran dalam lima kompetensi meliputi dimensi kompetensi kepribadian, dimensi kompetensi manajerial, dimensi kompetensi kewirausahaan, dimensi kompetensi supervisi, dan juga dimensi kompetensi sosial.

Selain itu, dalam Pasal 15 Permendikbud Nomor 6 Tahun 2018 Tentang Penugasan Guru Sebagai Kepala Sekolah, dinyatakan jika Tugas Pokok dan Fungsi Kepala Sekolah ialah sebagai berikut : 
1. Beban kerja Kepala Sekolah seluruhnya untuk melaksanakan tugas pokok manajerial, pengembangan kewirausahaan, dan supervisi kepada Guru dan tenaga kependidikan.

2. Beban kerja Kepala Sekolah bertujuan untuk mengembangkan sekolah dan meningkatkan mutu sekolah berdasarkan 8 (delapan) standar nasional pendidikan .

3. Saat terjadi kekurangan guru dalam satuan pendidikan tertentu, maka Kepala Sekolah bisa melaksanakan tugas pembelajaran maupun pembimbingan agar proses pembelajaran maupun pembimbingan tetap berlangsung dalam satuan pendidikan yang bersangkutan tersebut.

4. Kepala Sekolah yang melaksanakan tugas pembelajaran atau pembimbingan, tugas pembelajaran atau pembimbingan tersebut merupakan tugas tambahan di luar tugas pokoknya .

5. Beban kerja bagi kepala sekolah yang ditempatkan di SILN selain melaksanakan beban kerja juga melaksanakan promosi kebudayaan Indonesia.

Alhasil bahwa peran kepala sekolah dalam menjalankan tugasnya meliputi peran sebagai pemimpin, pembimbing, enterpreneur, edupreneur sekaligus sebagai pengawas (supervisor).

Supervisi (pengawasan) sangat diperlukan dalam setiap pelaksanaan program organisasi, termasuk pada organisasi pendidikan. Dalam dunia pendidikan, Supervisi merupakan fungsi administrasi pendidikan yang berarti aktivitas-aktivitas untuk menentukan kondisi-kondisi yang esensial yang akan menjamin tercapainya tujuan pendidikan. Jadi 16cientifi mempunyai pengertian yang luas. Dalam sebuah literature dikatakan bahwa supervisi adalah segala bantuan dari pemimpin sekolah yang tertuju kepada perkembangan kepemimpinan guru-guru dan personel sekolah lainnya di dalam mencapai tujuan-tujuan pendidikan. Ia berupa dorongan, bimbingan dan kesempatan bagi pertumbuhan keahlian dan kecakapan guru-guru seperti bimbingan dalam usaha dan pelaksanaan pembaharuan-pembaharuan dalam pendidikan dan pengajaran, pemilihan alatalat pelajaran dan metode mengajar yang lebih baik, cara-cara penilaian yang sistematis terhadap fase seluruh proses pengajaran dan sebagainya.

Dengan demikian pengertian 16cientifi adalah suatu aktifitas pembinaan yang direncanakan untuk membantu para guru dan pegawai sekolah lainnya dalam melakukan pekerjaan mereka secara efektif ( Ngalim Purwanto, 2009: 76 ). Supervisi pendidikan juga bisa diartikan sebagai segala usaha yang memberikan kesempatan bagi guru-guru untuk berkembang secara profesional sehingga mereka lebih maju lagi dalam melaksanakan tugas pokoknya, yaitu memperbaiki dan meningkatkan proses belajar mengajar.

Berdasarkan pengertian diatas maka supervisi adalah suatu upaya peningkatan kualitas pendidikan melalui suatu kegiatan yang dilakukan oleh supervisor pendidikan pada lembaga pendidikan formal dalam memberikan bantuan kepada kepala sekolah, guru dan siswa dalam mengatasi persoalan yang dihadapi selama proses pendidikan berlangsung.

\section{B. Supervisi Kelas}

Supervisi ini dilakukan dalam rangka menjamin kualitas (quality assurance) agar sesuai dengan tujuan pendidikan. Supervisi yang dilaksanakan oleh kepala sekolah, harus mampu melakukan berbagai pengawasan dan pengendalian untuk meningkatkan kinerja tenaga kependidikan. Pengawasan dan pengendalian ini merupakan kontrol agar kegiatan pendidikan di sekolah terarah 
pada tujuan yang telah ditetapkan. Pengawasan dan pengendalian juga merupakan tindakan preventif untuk mencegah agar para tenaga kependidikan tidak melakukan penyimpangan dan lebih berhati-hati dalam melaksanakan pekerjaannya.

Supervisi pendidikan adalah pembinaan yang berupa bimbingan atau tuntunan ke arah perbaikan situasi pendidikan pada umumnya dan peningkatan mutu mengajar dan belajar dan belajar pada khususnya. Sedangkan pengertian supervisi kelas adalah merupakan kegiatan pokok yang dilakukan oleh kepala sekolah dalam pengembangan situasi belajar mengajar agar memperoleh kondisi yang lebih baik, meskipun tujuan akhirnya tertuju pada hasil belajar siswa.

Ngalim Purwanto ( 2009;89 ) menyamakan istilah supervisi kelas dengan supervisi pengajaran, yakni kegiatankegiatan kepengawasan yang ditujukan untuk memperbaiki kondisi-kondisi baik personil maupun material yang memungkinkan terciptanya situasi belajar mengajar yang lebih baik demi tercapainya tujuan pendidikan.

Dengan demikian bahwa supervisi kelas adalah merupakan proses aktivitas untuk meningkatkan kemampuan profesionalitas guru dalam pengembangan peningkatan situasi belajar mengajar yang lebih baik.

\section{Tujuan dan Fungsi Supervisi}

Menurut N.A Ametembun dalam Tim Dosen administrasi Pendidikan UPI (2009 : 316 ) bahwa tujuan supervisi pendidikan adalah untuk mengembangkan situasi belajar mengajar yang baik serta memperhatikan beberapa faktor yang sifatnya khusus sehingga dapat membantu mencari dan menentukan kegiatan supervisi yang lebih efektif. Bahkan untuk membina Kepala sekolah dan guru-guru untuk lebih baik dalam memahami tujuan pendidikan sebenarnya dan peranan sekolah dalam mencapai tujuan serta mempersiapkan pesera didiknya menjadi anggota masyarakat yang efektif dan juga dapat untuk mengadakan diagnosis secara kritis terhadap tata kerja yang demokratis dan kooperqtif. Selain itu juga untuk dapat mengevaluasi kinerja kepala sekolah dan guru-gurunya dalam menjalankan aktivitasnya di sekolah.

Tujuan utama Supervisi adalah memperbaiki pengajaran (Neagly \& Evans, 1980; Oliva, 1984; Hoy \& Forsyth, 1986; Wiles dan Bondi, 1986; Glickman, 1990) dalam Moh. Badrus Sholeh, adalah memberikan bantuan teknis dan bimbingan kepada guru dan staf agar personil tersebut mampu meningkatkan kualitas kinerjanya, dalam melaksanakan tugas dan melaksanakan proses belajar mengajar secara operasional dapat dikemukakan beberapa tujuan konkrit dari 17cientifi pendidikan yaitu :

1. Meningkatkan mutu kinerja guru

a. Membantu guru dalam memahami tujuan pendidikan dan apa peran sekolah dalam mencapai tujuan tersebut

b. Membantu guru dalam melihat secara lebih jelas dalam memahami keadaan dan kebutuhan siswanya.

c. Membentuk moral kelompok yang kuat dan mempersatukan guru dalam satu tim yang efektif, bekerjasama secara akrab dan bersahabat serta saling menghargai satu dengan lainnya.

d. Meningkatkan kualitas pembelajaran yang pada akhirnya meningkatkan prestasi belajar siswa.

e. Meningkatkan kualitas pengajaran guru baik itu dari segi strategi, keahlian dan alat pengajaran.

f. Menyediakan sebuah sistim yang berupa penggunaan teknologi yang dapat membantu guru dalam pengajaran.

g. Sebagai salah satu dasar pengambilan keputusan bagi kepala sekolah untuk reposisi guru. 
2. Meningkatkan keefektifan kurikulum sehingga berdaya guna dan terlaksana dengan baik.

3. Meningkatkan keefektifan dan keefesiensian sarana dan prasarana yang ada untuk dikelola dan dimanfaatkan dengan baik sehingga mampu mengoptimalkan keberhasilan siswa.

4. Meningkatkan kualitas pengelolaan sekolah khususnya dalam mendukung terciptanya suasana kerja yang optimal yang selanjutnya siswa dapat mencapai prestasi belajar sebagaimana yang diharapkan.

5. Meningkatkan kualitas situasi umum sekolah sehingga tercipta situasi yang tenang dan tentram serta kondusif yang akan meningkatkan kualitas pembelajaran yang menunjukkan keberhasilan lulusan.

Adapun yang menjadi fungsi supervisi adalah :

1. Fungsi Meningkatkan Mutu Pembelajaran Ruang lingkupnya sempit, hanya tertuju pada aspek akademik, khususnya yang terjadi di ruang kelas ketika guru sedang memberikan bantuan dan arahan kepada siswa.

2. Fungsi Memicu Unsur yang Terkait dengan Pembelajaran Lebih dikenal dengan nama Supervisi Administrasi

3. Fungsi Membina dan Memimpin. Dalam pelaksanaannya seorang supervisor harus perlu memahami fungsi-fungsi supervisi yang merupakan tugas pokok dari supervisor pendidikan.
Menurut
Cici
Sutarsih

Manajemen Pendidikan 2009: 314 ) fungsi 18cientifi pendidikan adalah sebagai berikut:

1. Menyelenggarakan inspeksi

2. Penelitian hasil inspeksi berupa data

3. Penilaian

4. Latihan

5. Pembinaan

Makin jauh pembahasan tentang 18cientifi makin 18cient bahwa kunci 18cientifi bukan hanya membicarakan perbaikan itu sendiri, melainkan 18cientifi yang diberikan kepada guru-guru Dalam suatu analisa fungsi 18cientifi yang diberikan oleh Swearingen dalam Pedoman Pelaksanaan Supervisi Pendidikan Agama, Depag RI Ditjen Baga Islam, Jakarta, 2003., terdapat 8 fungsi 18cientifi, yakni:

1. Mengkoordinasi Semua Usaha Sekolah.

Koordinasi yang baik diperlukan terhadap semua usaha sekolah untuk mengikuti perkembangan sekolah yang makin bertambah luas dan usaha-usaha sekolah yang makin menyebar, diantaranya:

- Usaha tiap guru.

- Usaha-usaha sekolah.

- Usaha-usaha pertumbuhan jabatan.

2. Memperlengkapi Kepemimpinan Sekolah.

Yakni, melatih dan memperlengkapi guru-guru agar mereka memiliki ketrampilan dan kepemimpinan dalam kepemimpinan sekolah.

3. Memperluas Pengalaman.

Yakni, memberi pengalamanpengalaman baru kepada anggotaanggota staff sekolah, sehingga selalu anggota staff makin hari makin bertambah pengalaman dalam hal mengajarnya.

4. Menstimulasi Usaha-Usaha yang Kreatif.

Yakni, kemampuan untuk menstimulir segala daya kreasi baik bagi anak-anak, orang yang dipimpinnya dan bagi dirinya sendiri.

5. Memberikan Fasilitas dan Penilaian yang Kontinu.

Penilaian terhadap setiap usaha dan program sekolah misalnya, memiliki bahan-bahan pengajaran, buku-buku pengajaran, perpustakaan, cara mengajar, kemajuan murid-muridnya harus bersifat menyeluruh dan kontinyu.

6. Menganalisa Situasi Belajar

Situasi belajar merupakan situasi dimana semua faktor yang memberi kemungkinan bagi guru dalam memberi 
pengalaman belajar kepada murid untuk mencapai tujuan pendidikan.

7. Memberi Pengetahuan dan Ketrampilan pada Setiap Anggota Staf.

Supervisi berfungsi memberikan stimulus dan membantu guru agar mereka memperkembangkan pengetahuan dan ketrampilan dalam belajar.

8. Mengintegrasikan Tujuan dan Pembentukan Kemampuan.

Fungsi supervisi di sini adalah membantu setiap individu, maupun kelompok agar sadar akan nilai-nilai yang akan dicapai itu, memungkinkan penyadaran akan kemampuan diri sendiri.

Fungsi supervisor (pengawas) oleh karenanya menjadi penting, sebagaimana tertuang dalam Kepmen PAN Nomor 118/1996 yang menyebutkan bahwa pengawas diberikan tanggung jawab dan wewenang penuh untuk melaksanakan pengawasan terhadap pelaksanaan pendidikan, penilaian dan pembinaan teknis serta administratif pada satuan pendidikan.

\section{Teknik-teknik supervisi pendidikan}

Teknik yang dapat digunakan oleh supervisor dalam membantu guru untuk meningkatkan situasi belajar mengajar, baik secara kelompok maupun secara perorangan ataupun dengan cara langsung atau bertatap muka dan cara tak langsung atau melalui media komunikasi. Teknik tersebut bisa dilakukan dengan dua cara, yaitu, observasi kelas dan atau kunjungan kelas.

Letak perbedaan keduanya berdasarkan pandangan Made pidarta (2009:109) adalah sebagai berikut:

1. Observasi kelas

Membutuhkan waktu
pertemuan

o Supervisor tidak boleh mengintervensi guru dalam mengajar

o Dilaksanakan pada waktu proses pembelajaran berlangsung

o Ada umpan balik setelah proses berlangsung

2. Supervisi Kelas

\begin{tabular}{|c|c|}
\hline . & $\begin{array}{l}\text { Membutuhkan } \\
\text { sekurang-kurangnya } \\
\text { menit }\end{array}$ \\
\hline ק & $\begin{array}{l}\text { Mengamati sampel-sampel } \\
\text { prilaku yang dirasa masih } \\
\text { lemah }\end{array}$ \\
\hline & $\begin{array}{l}\text { Mengetahui kelemahan } \\
\text { sekaligus memperbaikinya }\end{array}$ \\
\hline & $\begin{array}{l}\text { Suppervisor bisa memperbaiki } \\
\text { langsung dalam proses } \\
\text { pembelajaran }\end{array}$ \\
\hline & $\begin{array}{l}\text { Dilakukan sebelum, pada } \\
\text { waktu pembelajaran, dan } \\
\text { sesudah proses pembelajaran } \\
\text { berlangsung }\end{array}$ \\
\hline & $\begin{array}{l}\text { Umpan balik boleh ada c } \\
\text { boleh tidak ada. }\end{array}$ \\
\hline
\end{tabular}

Teknik supervisi secara perorangan adalah pelaksanaan supervisi yang diberikan kepada guru tertentu yang mempunyai masalah khusus dan bersifat perorangan. Supervisor atau pengawas hanya berhadapan dengan seorang guru yang dipandang memiliki persoalan tertentu. Menurut Cicih Sutarsih ( 2009: 316) teknik-teknik supervisi yang dapat digunakan supervisor pendidikan antara lain :

1. Kunjungan kelas yang dilakukan secara berencana untuk dapat memperoleh gambaran tentang kegiatan belajar mengajar dikelas.

2. Pertemuan pribadi antara supervisor dengan guru untuk membicarakan masalah-masalah khusus yang dihadapi guru.

3. Rapat antar supervisor dengan para guru di sekolah, biasanya untuk membicarakan masalah-masalah 
umum yang menyangkut perbaikan atau peningkatan mutu pendidikan.

4. Kunjungan antar kelas atau antar sekolah merupakan suatu kegiatan yang terutama untuk saling menukarkan pengalaman 20cient guru atau kepala sekolah tentang usaha-usaha perbaikan dalam proses belajar mengajar.

5. Pertemuan-pertemuan kelompok kerja penilik, MKKS serta kelompok kerja guru, pusat kegiatan guru dan sebagainya, yang dilakukan oleh masing-masing kelompok kerja untuk menemukan masalah, mencari 20cientific 20 penyelesaian serta menerapkan 20 cientific 20 masalah yang tepat.

\section{E. Jenis-jenis supervisi}

Setiap kegiatan atau pekerjaan yang dilaksanakan disekolah ataupun dikantorkantor memerlukan adanya supervisi agar pekerjaan itu dapat berjalan dengan baik dan mencapai tujuan yang telah ditentukan. Mengingat banyaknya jenis pekerjaan yang dilakukan oleh guru-guru maupun staf tata usaha di sekolah, bahwa pelaksanaan supervisi ( Ngalim Purwanto : 2009: 88 ) dapat dibedakan menjadi:

1. Supervisi umum dan supervisi pengajaran

Yang dimaksud dengan supervisi umum di sini adalah yang dilaksanakan terhadap kegiatan-kegiatan yang secara tidak langsung berhubungan dengan usaha perbaikan pengajaran, misalnya supervisi kegiatan pengelolaan bangunan dan perlengkapan sekolah, supervisi terhadap kegiatan pengelolaan administrasi kantor, supervisi pengelolaan keuangan sekolah.

Sedangkan 20cientifi pengajaran ialah kegiatan-kegiatan pengawasan yang ditujukan untuk memperbaiki kondisikondisi baik personil maupun material yang memungkinkan terciptanya situasi belajar mengajar yang lebih baik demi tercapinya tujuan pendidikan.
2. Supervisi Klinis

Supervisi ini sebenarnya masuk kedalam supervisi pengajaran, karena prosedur pelaksanaannya lebih ditekankan kepada sebab-sebab atau kelemahan yang terjadi di dalam proses belajar mengajar dan kemudian secara langsung pula diusahakan bagaimana cara memperbaiki kekurangan tersebut. Supervisi ini difokuskan pada perbaikan pengajaran dengan melalui siklus yang sistematis dari tahap perencanaan, pengamatan dan anlsis intelektual yang intensif terhadap penampilan mengajar dengan tujuan untuk mengadakan perbaikan.

Pada awal perkembangannya, model supervisi klinis ini menggunakan 5 prosedur, yaitu:

1) Mendiskusikan hasil praobservasi. Kegiatan ini dimulai dengan meminta guru mengemukakan rancangan pembalajaran yang akan diberikan di kelas, yang dihadiri oleh supervisor. Guru mengemukakan suatu kegiatan mengajar tertentu dalam proses pembelajaran yang ia diskusikan dengan supervisor.

2) Supervosir mengobservasi, mengamati dengan seksama tentang perilaku guru yang sedang mengajar sambil mencatat hasil pengamatannya.

3) Strategi yang dipakai oleh guru dalam pembelajaran dianalisis oleh supervisor.

4) Mendiskusikan hasil supervisi. Supervisor memberikan hasil penilaiannya sebagai umpan balik terhadap guru yang bersangkutan, sambil 20cient stimulus agar guru mengembangkan gaya mengajarnya.

5) Supervisor dan guru menganalisis keadaan diri masing-masing. Keduanya melakukan refleksi dalam rangka perbaikan ke depan. 
3. Pengawasan melekat dan pengawasan fungsional

Dalam dunia pendidikan 21cientifi biasa juga disebut dengan pengawasan. Dalam hal ini suatu pengawasan yang memang sudah dengan sendirinya menjadi tugas dan tanggung jawab semua pimpinan dai tingkat atas sampai dengan pimpinan tingkat yang paling bawah dari semua organisasi atau lembaga. Oleh karena itu setiap pemimpin adalah juga sebagai pengawas, maka kepengawasan yang dilakukan disebut dengan pengawasan melekat. Tujuan pengawasan melakat ialah untuk mengetahui apakah pimpinan unit kerja dapat menjalankan fungsi pengawasan dan pengendalian yang melekat padanya dengan baik, sehingga apabila ada penyelewengan, pemborosan, korupsi, maka pimpinan unit kerja dapat mengambil tindakan koreksi sedini mungkin. Sedangkan pengawasan fungsional adalah kegiatan-kegiatan pengawasan yang dilakukan oleh orangorang yang fungsi jabatannya sebagai pengawas. Supervisi fungsional pada umumnya dilakukan oleh pengawas.

\section{F. Kepala Sekolah}

Kepala sekolah memiliki peran strategis dalam pengembangan sekolah. Untuk itu, kepala sekolah dituntut memiliki kompetensi dan profesionalisme yang memadai. Untuk memperlancar tugasnya maka perlu diadakan pendidikan dan pelatihan, serta penyiapan para calon kepala sekolah dan pengembangan keprofesian secara berkelanjutan. Kompetensi yang dimiliki oleh kepala sekolah akan sangat menetukan pelaksanaan pembelajaran di sekolah. Hal tersebut selaras dengan sebuah hipotesa bahwa "Jika kualitas kompetensi kepala sekolah tinggi maka ada korelasi yang bagus dalam melaksanakan proses pembelajaran."

Kegiatan utama pendidikan di lembaga pendidikan seperti sekolah dalam mewujudkan tujuannya adalah kegiatan pembelajaran di kelas, sehingga seluruh aktifitas organisasi sekolah bermuara pada pencapaian tujuan pembelajaran yang efektif dan efisien. Oleh karena itu, salah satu peran kepala sekolah sebagai supervisor sangat diperlukan dalam rangka pencapaian tujuan tersebut. Kepala sekolah harus mampu melakukan berbagai pengawasan dan juga pengendalian terhadap masyarakat sekolah, terutama sekali guru sebagai central core kegiatan pembelajaran di kelas.

Pengawasan dan pengendalian harus di lakukan oleh kepala sekolah secara 21cientif, dimulai dari pertemuan awal dengan guru yang bersangkutan, pelaksanaan 21cientifi kelas sampai pada umpan balik dari kepala sekolah kepada guru yang disupervisi. Berikut ini rangkaian kegiatan pelaksanaan 21cientifi kelas oleh kepala sekolah:

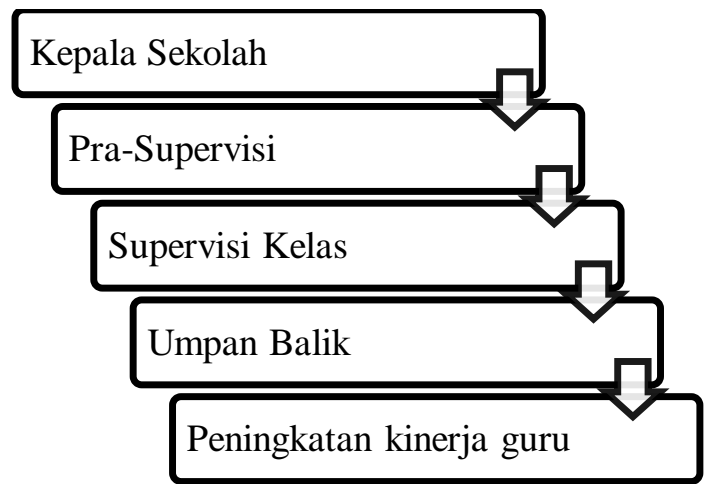

\section{G. Pelaksanaan Supervisi Kelas oleh Kepala Sekolah}

Sebelum proses belajar mengajar berlangsung, seorang guru hendaknya mempersiapkan terlebih dahulu administrasi mengajarnya, Baik itu silabus, RPP, bahan ajar, serta media dan metode yang digunakan. Kesiapan seorang guru harus betul-betul diperhatikan, yang tentunya berimbas pada keberhasilan proses belajar mengajar di kelas.

Mengenai hal tersebut, kepala sekolah juga memiliki andil yang cukup signifikan. Kepala sekolah seyogyanya melakukan pengawasan terhadap keberlangsungan proses belajar mengajar. Tentunya pengawasan tersebut bertujuan 
tidak lain dan tidak bukan adalah untuk meningkatkan mutu kegiatan belajar mengajar yang dilaksanakan di lembaga yang bersangkutan.

Sesuai dengan Permendiknas Nomor 13 Tahun 2007 tentang Standar Kepala Sekolah bahwa dalam prakteknya kepala sekolah sebagai supervisor harus memiliki 3 kompetensi, yaitu :

1. Merencanakan program supervisi akademik dalam rangka peningkatan profesionalisme guru. Dimensi kompetensi yang pertama ini memiliki indikator sebagai berikut:

a. Menyusun program supervisi akademik

b. Merumuskan tahapan teknik supervisi akademik

c. Menjabarkan tujuan supervisi akademik pada masing-masing lingkup pelaksanaan dan evaluasi pembelajaran

d. Menggunakan pendekatan supervisi akademik yang efektif

e. Menyusun prosedur monitoring dan evaluasi supervisi akademik

f. Merumuskan pencapaian tujuan supervisi akademik (output)

2. Melaksanakan supervisi akademik terhadap guru dengan menggunakan pendekatan dan teknik supervisi yang tepat.

Indikatornya adalah sebagai berikut:

a. Melaksanakan supervisi akademik yang didasarkan pada kebutuhan dan masalah nyata yang dihadapi oleh guru

b. Membangun hubungan dengan guru dan semua pihak yang terlibat dalam kegiatan supervisi berdasarkan prinsipprinsip supervisi akademik

c. Menggunakan pendekatan dan teknik supervisi akademik yang tepat dan sesuai dengan tujuan supervisi akademik d. Memecahkan masalah pengembangan pembelajaran supervisi akademik

e. Menggunakan teknologi informasi untuk mendukung kegiatan supervisi akademik

3. Menindaklanjuti hasil supervisi akademik terhadap guru dalam rangka peningkatan professionalisme guru.

Indikator dari kompetensi terakhir ini adalah sebagai berikut:

a. Merumuskan analisis pencapaian dampak supervisi akademik (outcome)

b. Mengembangkan analisis pengukuran pencapaian hasil langsung (output) supervisi akademik

c. Melakukan analisis hasil evaluasi untuk kepentingan tindak lanjut

d. Mengembangkan program tindak lanjut berdasarkan hasil evaluasi supervisi akademik.

e. Menentukan langkah-langkah perbaikan dan peningkatan kompetensi guru.

Berdasarkan Permendikbud tersebut Kepala sekolah harus membuat site plan Supervisi. Selain kegiatan perencanaan, kepala sekolah juga menjadi eksekutor pelaksanaan supervisi, dan yang terakhir, kepala sekolah harus bisa memberikan umpan balik atau kegiatan tindak lanjut dari hasil supervisi yang telah dilaksanakan sebelumnya.

Contoh Format bentuk-bentuk item yang akan diukur dan dievaluasi dalam proses pengawasan (supervisi) sesuai dengan Permendiknas Nomor 13 Tahun 2007 dapat digambarkan dalam bentuk table supervisi sebagaimana tertera berikut ini:

\section{Instrumen Penilaian Pra Supervisi Siklus 1}

Nama Sekolah 
Nama Guru

Identitas Mata Pelajaran

Pertemuan ke-

Kelas/Semester

Tahun pelajaran

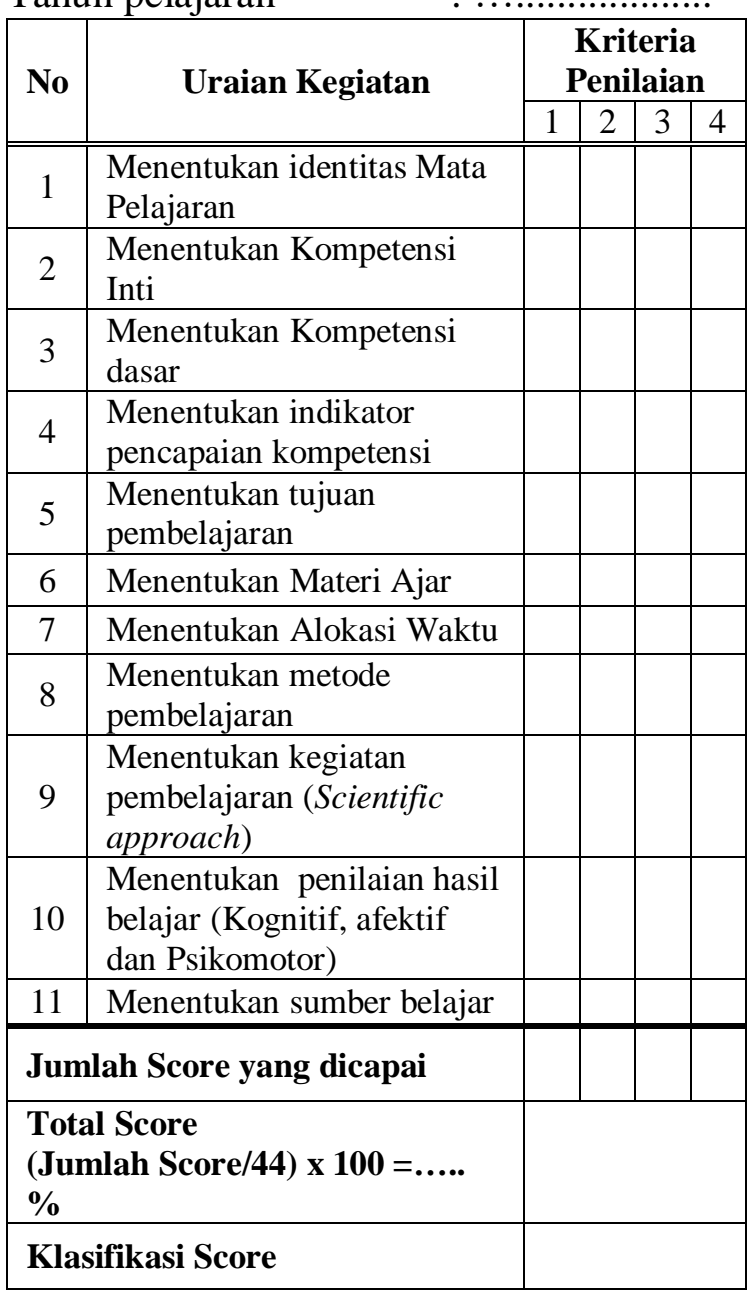

\section{Klasifikasi Score :}

A : Baik Sekali ( $90-100)$

B : Baik $\quad(80-89)$

C : Cukup $\quad(70-79)$

D : Kurang $\quad(\leq 69 \quad)$

Yang disupervisi

Kepala Sekolah

\section{Instrumen Supervisi kelas}

\section{Siklus 2}

Nama Guru

Mata Pelajaran
$\mathrm{KI} / \mathrm{KD}$

Smt/Kelas

Jam Pelajaran ke-

\begin{tabular}{|c|c|c|c|c|c|c|c|}
\hline \multirow{2}{*}{ No } & \multirow{2}{*}{$\begin{array}{c}\text { ASPEK YANG } \\
\text { DIAMATI }\end{array}$} & \multicolumn{5}{|c|}{ SKOR } & \multirow{2}{*}{$\mathbf{K e}$} \\
\hline & & 1 & 2 & 3 & 4 & 5 & \\
\hline \multirow[t]{15}{*}{1} & $\begin{array}{l}\text { ADMINISTRASI } \\
\text { PEMBELAJARAN }\end{array}$ & & & & & & \\
\hline & $\begin{array}{l}\text { Memiliki dokumen } \\
\text { kurikulum }\end{array}$ & & & & & & \\
\hline & $\begin{array}{l}\text { Memiliki dokumen } \\
\text { kurikulum muatan } \\
\text { lokal }\end{array}$ & & & & & & \\
\hline & $\begin{array}{l}\text { Memiliki program } \\
\text { semester dan } \\
\text { tahunan }\end{array}$ & & & & & & \\
\hline & Menyusun silabus & & & & & & \\
\hline & Membuat RPP & & & & & & \\
\hline & $\begin{array}{l}\text { Memiliki buku } \\
\text { pegangan siswa }\end{array}$ & & & & & & \\
\hline & $\begin{array}{l}\text { Memiliki buku } \\
\text { pegangan guru }\end{array}$ & & & & & & \\
\hline & $\begin{array}{l}\text { Memiliki media, } \\
\text { alat praga/alat } \\
\text { bantu pembelajaran }\end{array}$ & & & & & & \\
\hline & Memiliki buku nilai & & & & & & \\
\hline & $\begin{array}{l}\text { Memiliki buku } \\
\text { analisis ulangan } \\
\text { harian }\end{array}$ & & & & & & \\
\hline & $\begin{array}{l}\text { Memiliki buku } \\
\text { program perbaikan } \\
\text { dan pengayaan }\end{array}$ & & & & & & \\
\hline & $\begin{array}{l}\text { Memiliki buku } \\
\text { bimbingan dan } \\
\text { konseling }\end{array}$ & & & & & & \\
\hline & $\begin{array}{l}\text { Memiliki jadwal } \\
\text { pelajaran }\end{array}$ & & & & & & \\
\hline & $\begin{array}{l}\text { Memiliki kalender } \\
\text { pendidikan }\end{array}$ & & & & & & \\
\hline \multirow[t]{9}{*}{ II } & $\begin{array}{l}\text { ADMINISTRASI } \\
\text { KELAS }\end{array}$ & & & & & & \\
\hline & $\begin{array}{l}\text { Memiliki daftar } \\
\text { kelas }\end{array}$ & & & & & & \\
\hline & $\begin{array}{l}\text { memiliki daftar } \\
\text { hadir siswa }\end{array}$ & & & & & & \\
\hline & $\begin{array}{l}\text { Memiliki papan } \\
\text { absen harian siswa }\end{array}$ & & & & & & \\
\hline & $\begin{array}{l}\text { Memiliki grafik } \\
\text { absen }\end{array}$ & & & & & & \\
\hline & $\begin{array}{l}\text { Memiliki buku } \\
\text { mutasi siswa }\end{array}$ & & & & & & \\
\hline & $\begin{array}{l}\text { Memiliki buku } \\
\text { penerimaan raport }\end{array}$ & & & & & & \\
\hline & $\begin{array}{l}\text { Memiliki daftar } \\
\text { infentaris kelas }\end{array}$ & & & & & & \\
\hline & $\begin{array}{l}\text { Memiliki denah } \\
\text { kelas }\end{array}$ & & & & & & \\
\hline
\end{tabular}




\begin{tabular}{|l|l|l|l|l|l|l|l|}
\hline $\begin{array}{l}\text { Memiliki catatan } \\
\text { prestasi siswa } \\
\text { (akademik, non } \\
\text { akademik) }\end{array}$ & & & & & & & \\
\hline $\begin{array}{l}\text { Memiliki buku } \\
\text { tamu }\end{array}$ & $\begin{array}{l}\text { Memiliki catatan } \\
\text { perkembangan } \\
\text { kepribadian siswa }\end{array}$ & & & & & & \\
\hline $\begin{array}{l}\text { Memiliki buku } \\
\text { catatan } \\
\text { perkembangan } \\
\text { kesehatan siswa }\end{array}$ & & & & & & \\
\hline Jumlah Score & & & & & & \\
\hline Total Score & & & & & \\
\hline Klasifikasi Score & & & & \\
\hline
\end{tabular}

Rumus :

Jumlah Score/Score maksimal $\times 100=$ ...\%

\section{Klasifikasi Score :}
A : Baik Sekali $(90-100)$
B : Baik $\quad(80-89)$
C: Cukup $\quad(70-79)$
D : Kurang $\quad(\leq 69)$

Yang disupervisi

Kepala Sekolah

3. Instrumen Umpan balik

Siklus 3

Nama Guru

Mata Pelajaran

\begin{tabular}{|l|l|l|l|}
\hline NO & \multicolumn{1}{|c|}{$\begin{array}{c}\text { Aspek yang } \\
\text { diidentifikasi }\end{array}$} & $\begin{array}{c}\text { Masalah } \\
\text { yang } \\
\text { ditemukan }\end{array}$ & $\begin{array}{c}\text { Tindak } \\
\text { Lanjut }\end{array}$ \\
\hline 1 & $\begin{array}{l}\text { Administrasi } \\
\text { Pembelajaran }\end{array}$ & & \\
\hline 2 & $\begin{array}{l}\text { Proses } \\
\text { Pembelajaran }\end{array}$ & & \\
\hline 3 & Kompetensi guru & & \\
\hline 4 & Penilaian Siswa & & \\
\hline 5. & $\ldots \ldots \ldots \ldots \ldots \ldots \ldots . . . \ldots \ldots$ & & \\
\hline
\end{tabular}

Kesimpulan :

\section{Saran :}

Yang disupervisi

Kepala Sekolah

\section{SIMPULAN DAN SARAN}

\section{A. Simpulan}

Berdasarkan kajian-kajian literature yang sudah dipaparkan di atas bisa disimpulkan bahwa

1. Salah satu tugas dan fungsi kepala sekolah dalam suatu lembaga pendidikan adalah sebagai supervisor yang bertanggung jawab terhadap efektifitas pelaksanaan pembelajaran di kelas. Yang harus dilakukan oleh kepala sekolah dalam melaksanakan kegiatan supervisi adalah melakukan perencanaan kegiatan supervisi, melaksanakan supervisi dan menindaklanjuti kegiatan supervisi dengen memberikan umpan balik kepada guru yang disupervisi dalam rangka perbaikan dan peningkatan aktifitas pembelajaran selanjutnya.

2. Upaya yang dilakukan kepala sekolah dalam rangka 
meningkatkan profesionalisme guru adalah dengan melaksanakan serangkaian proses supervisi secara sistemik. Tidak hanya berhenti di situ saja, kepala sekolah harus melaksanakan kegiatan supervise secara periodik.

3. Teknik yang dapat digunakan oleh kepala sekolah sebagai supervisor dalam membantu guru untuk meningkatkan situasi belajar mengajar, baik secara kelompok maupun secara perorangan ataupun dengan cara langsung atau bertatap muka dan cara tak langsung atau melalui media komunikasi. Teknik tersebut bisa dilakukan dengan dua cara, yaitu, observasi kelas dan atau kunjungan kelas.

\section{B. Saran}

Peningkatan profesionalisme guru dalam kompetensinya sebagai pengelola kegiatan belajar mengajar di kelas merupakan sesuatu yang urgen dilakukan oleh kepala sekolah dengan melaksanakan salah satu tugas dan fungsinya sebagai supervisor.

Supervisi sudah seharusnya dilaksanakan dengan serius, tidak hanya sebatas menggugurkan tugas dan fungsi kepala sekolah saja, tetapi benar-benar lebih kepada pengembangan serta peningkatan kompetensi guru dalam mengelola kegiatan belajar mengajar di kelas.

\section{DAFTAR PUSTAKA}

Arikunto, Suharsimi. (2009). Dasar-Dasar Supervisi, Cet. III. Jakarta: Rineka Cipta.

Asmani, J.M. (2012). Tips Efektif Supervisi Pendidikan Sekolah. Yogyakarta: Diva Press.

Bush, Tony. Marianne Coleman. (2008). Manajemen Strategis Kepemimpinan Pendidikan. Yogyakarta: Diva Press.
Djamarah, SB (2000). Guru dan Anak Didik dalam Interaksi edukatif. Jakarta: Rineka Cipta.

Gunawan, Ary H. (2002). Administrasi Sekolah Administrasi Pendidikan Mikro, Cet. I. Jakarta: Rineka Cipta.

Hasbullah. (2005). Dasar-Dasar Ilmu Pendidikan, Edisi Revisi. Jakarta: Rajawali Pers.

Kementerian Pendidikan dan Kebudayaan

Republik Indonesia. (2016).

Supervisi Akademik. Jakarta.

Direktorat jenderal Guru dan Tenaga Kependidikan

Marno \& Triyo Supriyatno. (2008). Manajemen dan Kepemimpinan Pendidikan Islam. Bandung: Refika Aditama.

Mulayasa, E. (2009). Menjadi Kepala Sekolah Profesional. Bandung: Remaja Rosdakarya.

Pidarta, Made. (2009), Supervisi Pendidikan Kontekstual. Jakarta: Rineka Cipta

Rusman. (2011). Manajmen Kurikulum. Jakarta: Rajawali Press

Sahertian, Piet A. (2000). Konsep Dasar dan Teknik Supervisi Pendidikan Dalam Rangka Pengembangan Sumber Daya Manusia, Cet. I. Jakarta: Rineka Cipta.

Sonhaji. (2006). Pembaharuan Sistem Manajemen Lembaga Pendidikan. Malang: Program Pascasarjana Universitas Negeri Malang

Sugiono. (2005). Memahami Penelitian Kualitatif . Bandung: Alfabeta.

Sukmadinata dan Nana S. (2012). Metode Penelitian Pendidikan. Bandung: Rosda.

Wahjosumidjo. (2010). Kepemimpinan Kepala Sekolah, Tinjauan Teoritis dan Permasalahannya. Jakarta: Raja Grafindo Persada

Wahyudi. (2009). Kepemimpinan Kepala Sekolah dalam Organisasi Pembelajar. Bandung: Alfabeta 